\section{Resistance of Hybrid Citrus Rootstocks to a Mediterranean Biotype of Tylenchulus semipenetrans Cobb}

\author{
S. Verdejo-Lucas ${ }^{1}$ \\ Institut de Recerca i Tecnologia Agroalimentàries, Departament Protecció \\ Vegetal, Crta. de Cabrils s/n, 08348 Cabrils (Barcelona), Spain
}

F.J. Sorribas

E.S.A.B. Departament Agronomia, Comte d'Urgell 187, 08036 Barcelona, Spain

\author{
J.B. Forner and A. Alcaide \\ Instituto Valenciano de Investigaciones Agrarias, Departamento Citricultura, \\ Apartado oficial, 46113, Moncada, Valencia, Spain
}

Additional index words. Citrus sp., nematodes, Poncirus trifoliata, susceptibility

\begin{abstract}
The response of 52 citrus hybrid rootstocks to a Mediterranean biotype of Tylenchulus semipenetrans Cobb was determined in greenhouse tests. Seven selections of the cross 'Cleopatra' mandarin [Citrus reshni Hort. x Poncirus trifoliata (L.) Raf], and one of Citrus volkameriana Pasq. $x$ P. trifoliata did not support nematode reproduction and were considered as highly resistant to the citrus nematode. The nematode showed very low infectivity and reproductive potential on seven additional selections of 'Cleopatra' mandarin $\times P$. trifoliata, one of 'King' mandarin $\times P$. trifoliata, and two $C$. volkameriana $\times P$. trifoliata. These selections were considered as nematode resistant. All the selections with 'Troyer' citrange [Citrus sinensis (L). Osbeck X P. trifoliata (L.) Raf] in their parentage supported nematode reproduction but showed different levels of susceptibility.
\end{abstract}

The citrus nematode infects citrus worldwide and is associated with poor growth of young citrus trees planted in infested groves and with poor performance of mature citrus trees (Duncan and Cohn, 1990). The host range of $T$. semipenetrans includes all Citrus species and most hybrids of citrus with other members of the Rutaceae family, such as trifoliate orange [Poncirus trifoliata (L.) Raf]. Nonrutaceous plants, such as grape (Vitis vinifera L.), olive (Olea europea L.) and persimmon (Diospyros sp.), are also hosts of the citrus nematode. The only germplasm source of citrus nematode resistance that has been incorporated into commercially acceptable citrus rootstocks is derived from $P$. trifoliata (Kaplan, 1990). Some selections of $P$. trifoliata have a high level of resistance to populations of $T$. semipenetrans, whereas others are moderately susceptible (Baines et al., 1969; Cameron et al., 1954; Crozzoli and González, 1989; Ducharme, 1948; Feder, 1968; McCarty et al., 1979; O’Bannon and Ford, 1977; Reddy

\footnotetext{
Received for publication 5 May 1999. Accepted for publication 27 July 1999 . We thank Drs. D.T. Kaplan and E.A. Tzortzakakis for critical reading of the manuscript. This work was financed by the Instituto Nacional de Investigaciones Agrarias (I.N.I.A.) grants No. SC94-037-C2-2 and SC98-103-C2-2. The cost of publishing this paper was defrayed in part by the payment of page charges. Under postal regulations, this paper therefore must be hereby marked advertisement solely to indicate this fact. ${ }^{1}$ To whom reprint requests should be addressed (email: soledad.verdejo@irta.es)
}

and Agarwal, 1987). Trifoliate orange hybridizes readily with most Citrus sp., and many of the resulting hybrids inherit resistance to the citrus nematode (Cameron et al., 1969). Of these, the hybrid rootstock 'Swingle' citrumelo (Citrus paradisi Macf. $x$ P. trifoliata) is highly resistant to the citrus nematode in Florida (Kaplan and O'Bannon, 1981), Italy (Lo Giudice and Inserra, 1980), and Venezuela (Crozzoli and Funes, 1992). Duncan et al. (1994) have reported a population of $T$. semipenetrans capable of overcoming resistance in 'Swingle' citrumelo in Florida, but this population appears to be confined to the nursery site where it was detected. Other potential sources of citrus nematode resistance among noncultivated Rutaceous plants have been reported (Baines et al., 1960; Kaplan and O'Bannon, 1981), but these genera are not horticulturally acceptable as rootstocks and their hybridization with Citrus sp. has had limited success.

Although $P$. trifoliata and 'Swingle' citrumelo are resistant to $T$. semipenetrans, both rootstocks have important limitations to use in Spanish soils because of their poor performance in calcareous and alkaline soils. Therefore, new rootstocks are still needed to satisfy regional demands. A breeding program was initiated at the Instituto Valenciano de Investigaciones Agrarias (IVIA), Moncada, Valencia, to identify new citrus rootstocks tolerant to tristeza virus and adapted to Spanish conditions, particularly calcareous soils and salinity. Many of the hybrids obtained in that program have $P$. trifoliata as the male progenitor because of its tristeza tolerance (Forner and Alcaide, 1994). In a previous study, the response of 22 citrus hybrid rootstocks to a Mediterranean biotype of $T$. semipenetrans was determined in a greenhouse test (Verdejo-Lucas et al., 1997a). This study reports the response of 44 additional citrus hybrid rootstocks that had not been tested previously to the same biotype of the citrus nematode. Eight rootstocks evaluated previously as hosts of citrus nematode were also included.

\section{Materials and Methods}

Procedure. The procedure described by Kaplan (1990) for screening citrus rootstocks for resistance to $T$. semipenetrans was followed in this study, with some modifications as previously reported (Verdejo-Lucas et al., 1997a). Briefly, germinated seeds of each selection were transplanted singly to black plastic bags (1.5-L capacity) containing a steamsterilized potting mixture, and plants were maintained in a greenhouse for 12 months before adding the nematode inoculum. The latter was obtained from $T$. semipenetransinfected citrus roots collected from a 14-yearold citrus orchard of 'Washington Navel' orange on 'Troyer' citrange. This citrus nematode population had been identified as the Mediterranean biotype of the nematode using a differential host test (Verdejo-Lucas et al., 1997b). Citrus roots were blender macerated (McSorley et al., 1984) to estimate the number of eggs and second-stage juveniles (J2) per $g$ root. Plants were inoculated with $\approx 1 \times 10^{4}$ eggs $+\mathrm{J} 2$ per plant. The rootstocks assessed were selected because of their tolerance to citrus tristeza virus. The selections included in each of the three experiments performed are indicated in Tables 1, 2, and 3. Selections without $P$. trifoliata in their parentage were also included in the experiments to determine their relative susceptibility to $T$. semipenetrans. The selections 03.01.40,03.01.8,03.01.42,03.01.5, 03.01.18, 03.01.46, 02.04.18, and 02.03.24 included in the third experiment had been tested previously but were retested again to verify their response (Verdejo-Lucas et al., 1997a, and Table 2).

The experiments were arranged in randomized complete blocks, and each rootstocknematode combination was replicated seven times. The temperature of the greenhouse ranged from 16 to $26^{\circ} \mathrm{C}$ during the 6 months of the experiment. At harvest, roots were washed free of soil, weighed, and then frozen at $-20{ }^{\circ} \mathrm{C}$ until processed. When required, roots were thawed at room temperature, and nematodes extracted from the entire root system by blender maceration (McSorley et al., 1984) using a $0.5 \%$ sodium hypochlorite solution. Nematodes collected on a $25-\mathrm{mm}$ screen were subjected to centrifugation and sugar flotation to remove root debris (Jenkins, 1964). The infectivity (females/g root) and reproductive potential (eggs $+\mathrm{J} 2 / \mathrm{g}$ root) of $T$. semipenetrans were considered as indicators of the response of the rootstocks to the nematode. 
Table 1. Numbers of females, second stage juveniles, and eggs of a Mediterranean biotype of Tylenchulus semipenetrans per gram of root for citrus hybrid rootstocks. Expt.1. ${ }^{z}$

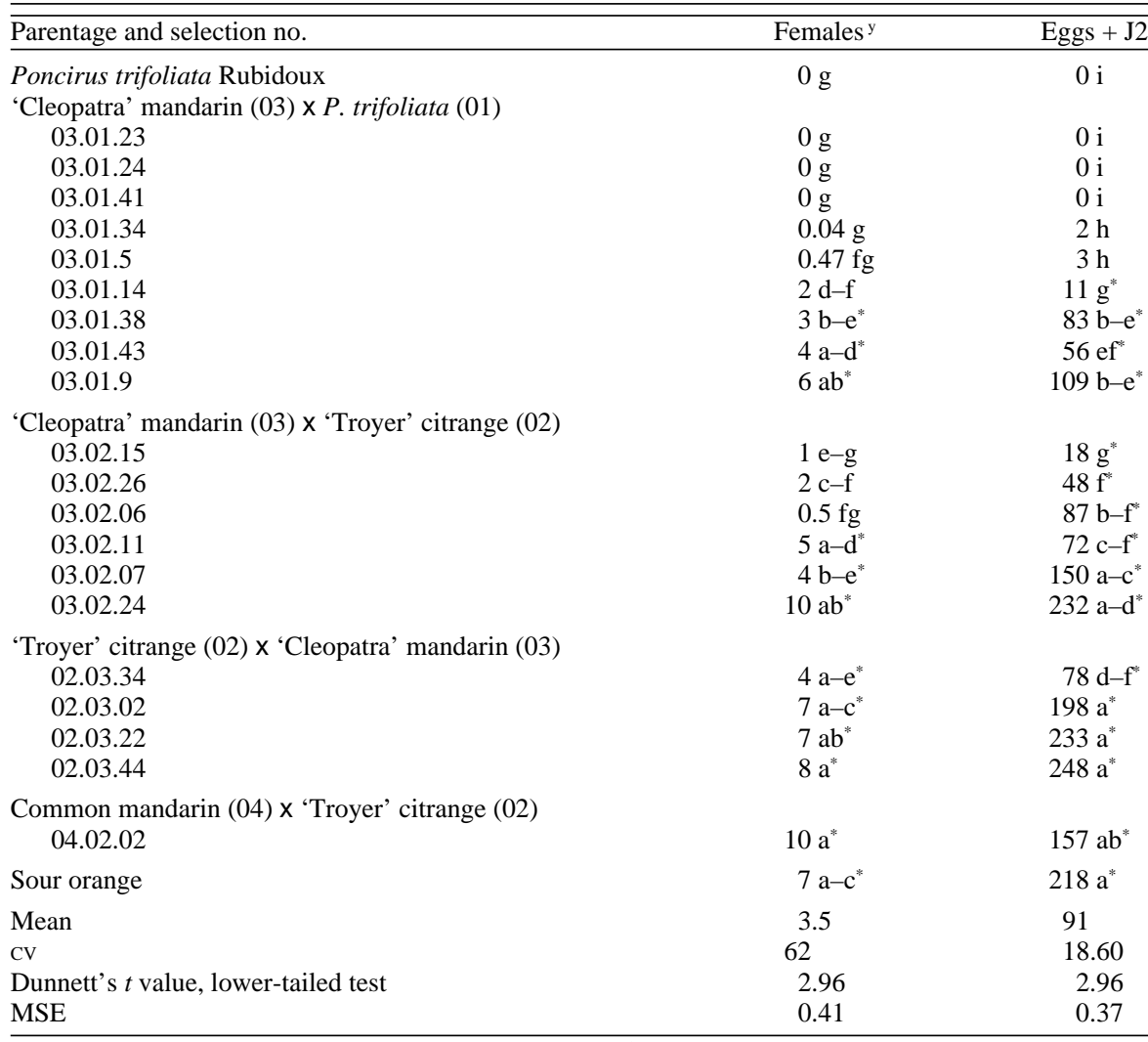

${ }^{2}$ Rootstocks were exposed to an inoculum level of $1 \times 10^{4}$ nematode eggs $+\mathrm{J} 2$ per plant for 6 months in a greenhouse.

'Data were transformed $\log (\mathrm{x}+1)$. Means separation within columns by Duncan's multiple range test, $P$ $\leq 0.05$.

"Difference between $P$. trifoliata and rootstock tested significant according to Dunnett's $t$ tests, $P \leq 0.05$.

Statistical analysis of data. The host status of the rootstocks was established by comparing nematode infectivity and reproductive potential with those on the susceptible sour orange. Data were transformed to $\log (x+1)$ and subjected to analysis of variance, and the means were separated by Duncan's multiple range test $(P \leq 0.05)$. A multiple comparison procedure that compares all treatments with a single control was used to identify rootstocks expressing resistance to T. semipenetrans. Host suitability of individual rootstocks was compared with that of the standard of resistance, $P$. trifoliata, by Dunnett's $t$ tests $(P \leq 0.05)$ (Dunnett, 1955). Data on number of females per plant and eggs produced per female were transformed to $(\log x+1)$ and subjected to regression analysis to determine the relationship between fertile females and their fecundity in rootstocks that differed in susceptibility to the citrus nematode. Individual plants with no females were excluded from the analysis. Analysis of variance indicated that nematode reproduction on susceptible sour orange was similar in the three experiments. Hence, nematode infectivity and reproductive potential on selections of 'Troyer' citrange $x$ 'Cleopatra' mandarin (02.03) were compared with those on selections of 'Cleopatra' mandarin X 'Troyer' citrange (03.02) by Student's $t$ test $(P \leq 0.05)$ to determine if there was any cytoplasmatic inheritance.

\section{Results}

The Mediterranean biotype of $T$. semipenetrans did not reproduce on $P$. trifoliata. In Expt. 1, the selections from crosses of 'Cleopatra' mandarin XP. trifoliata 03.01.23, 03.01.24, and 03.01. 41 did not support nematode reproduction (Table 1). These selections were considered as highly resistant to $T$. semipenetrans. A very low number of females and of eggs $+\mathrm{J} 2$ were recovered from two additional selections of the same cross (03.01.34 and 03.01.5), and these selections could be considered as nematode-resistant. The remaining four selections of 'Cleopatra' mandarin X P. trifoliata supported nematode reproduction. All selections from crosses with 'Troyer' citrange supported various levels of nematode reproduction (Table 1). In Expt. 2, the citrus nematode did not reproduce on the selections from crosses of 'Cleopatra' mandarin X P. trifoliata 03.01.27, 03.01.28 and 03.01.33, or of C. volkameriana $\times$ P. trifoliata 23.01.98 (Table 2). As in the previous experiment, these selections were considered as highly resistant to the population of the Mediterranean biotype of $T$. semipenetrans tested. The nematode showed a very low infectivity ( $<1$ female per gram root) and reproductive potential ( $<15$ eggs $+\mathrm{J} 2$ per gram root) on three additional crosses of 'Cleopatra' mandarin $\mathrm{x}$ P.trifoliata (03.01.16,03.01.20 and 03.01.26), and on two of $C$. volkameriana $\times P$. trifoliata (23.01.17 and 23.01.29). The remaining selections included in this experiment supported nematode reproduction in varying degrees. Numbers of females and of eggs $+\mathrm{J} 2$ per gram of root were higher $(P \leq 0.05)$ on three selections of 'Cleopatra' mandarin $x$ 'Troyer' citrange, two of 'Troyer' citrange $x$ 'Cleopatra' mandarin, and on 'Mineola' tangelo $\times P$. trifoliata than on the susceptible sour orange (Table 2). In Expt. 3, the selection 03.01.40 of 'Cleopatra' mandarin $\times$ P. trifoliata was considered as highly resistant to the citrus nematode, whereas the selections 03.01.8, 03.01.42, 03.01.5, and the selection of 'King' mandarin $x$ P. trifoliata $05.01 .24 \mathrm{~B}$ were resistant (Table $3)$.

A total of 20 selections from crosses of 'Troyer' citrange and 'Cleopatra' mandarin were tested, and each of them supported nematode reproduction (Tables 1, 2, and 3). However, the numbers of females per gram of root in some of these selections without $P$.trifoliata parentage, such as 03.02.15, 03.02.26,03.02.6 (Table 1), 02.03.24 (Table 2), 03.02.12 and 02.03.18 (Table 3) did not differ from those on $P$. trifoliata. This was probably due to the great variability among individual plants (Fig. 1). The numbers of females produced per plant and their fecundity was negatively correlated, that is, rootstocks supporting higher infectivity showed lower reproductive potential. This relationship was also found in rootstocks that expressed resistance to $T$. semipenetrans. Cytoplasmatic inheritance was not evident in the resistance of progeny from crosses of 'Troyer' citrange and 'Cleopatra' mandarin. Overall, the average numbers of females and of eggs $+\mathrm{J} 2$ per gram of root produced by 'Troyer' citrange $x$ 'Cleopatra' mandarin (02.03) and 'Cleopatra' mandarin $x$ 'Troyer' citrange (03.02) were similar (Table 4).

\section{Discussion}

The rootstocks included in our studies had shown tolerance to CTV in previous studies (Forner, personal communication). The citrus nematode is the most frequent and abundant plant-parasitic nematode that occurs in Spanish citrus orchards, but other pest nematode species are also present (Bello et al., 1985). The resistance found in trifoliate orange and 'Swingle' citrumelo have shown a useful level of durability (Roberts, 1992). At present, these two rootstocks are the only commercially available rootstocks with effective resistance to $T$. semipenetrans; however, horticultural characteristics preclude their use in Spanish soils.

In this study, we have only considered rootstocks to be resistant to $T$. semipenetrans if citrus nematode infectivity and reproductive potential (females and eggs $+\mathrm{J} 2$ per gram of root, respectively) were similar to those of trifoliate orange. These resistant rootstocks included 14 hybrids with 'Cleopatra' mandarin, three with $C$. volkameriana, and one with 'King' mandarin, which represented $64 \%$ of the selections from crosses with $P$. trifoliata. Some of these hybrids possess other characteristics that are of interest for citrus produc- 
Table 2. Numbers of females, second stage juveniles, and eggs of a Mediterranean biotype of Tylenchulus semipenetrans per gram of root for citrus hybrid rootstocks. Expt. $2 .^{2}$

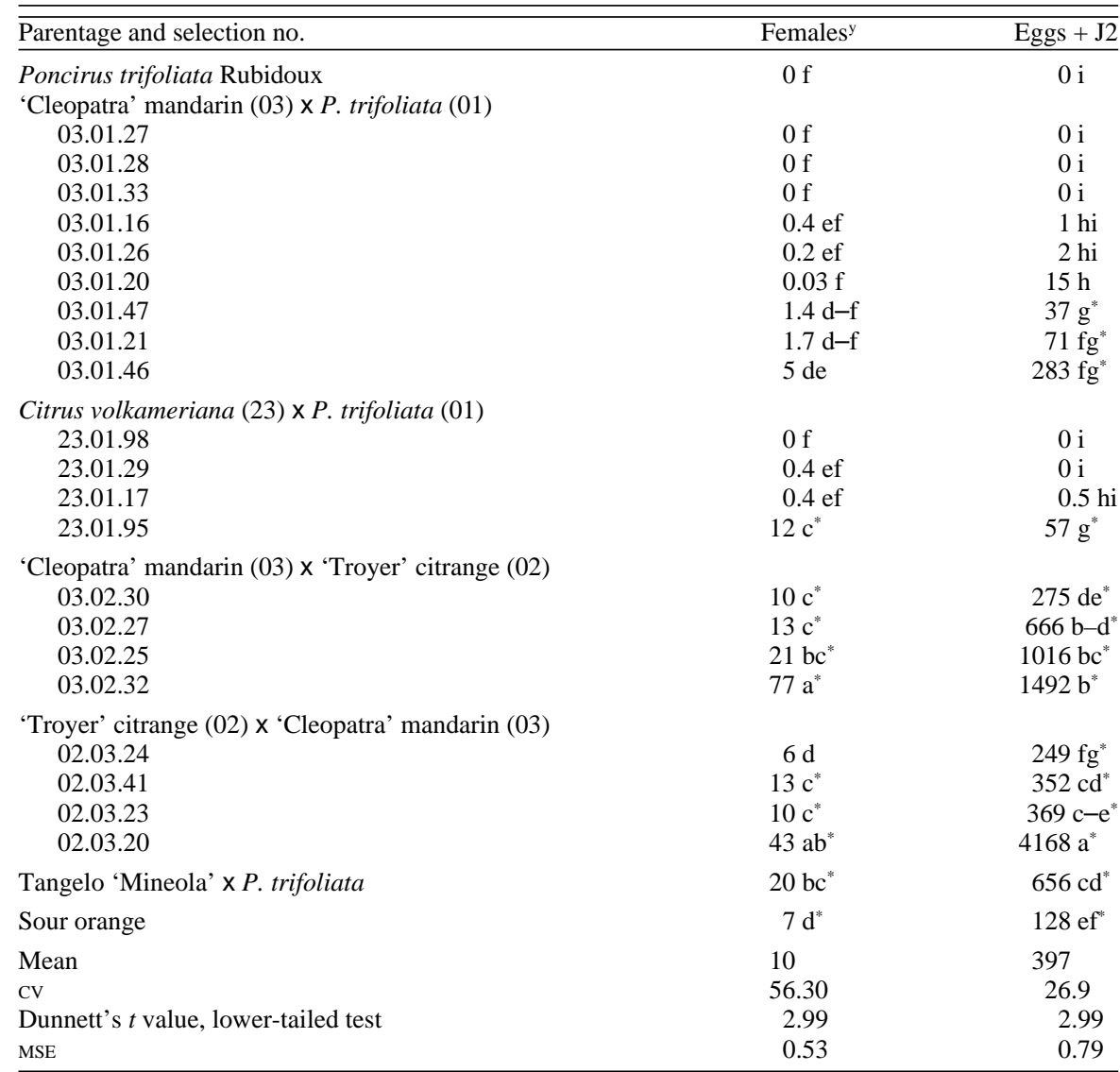

${ }^{2}$ Rootstocks were exposed to an inoculum level of $1 \times 10^{4}$ nematode eggs $+\mathrm{J} 2$ per plant for 6 months in a greenhouse.

'Data were transformed $\log (\mathrm{x}+1)$. Means separation within columns by Duncan's multiple range test, $P \leq 0.05$.

"Difference between $P$. trifoliata and rootstock tested significant according to Dunnett's $t$ tests, $P \leq 0.05$

Table 3. Numbers of females, second stage juveniles, and eggs of a Mediterranean biotype of Tylenchulus semipenetrans per gram of root for citrus hybrid rootstocks. Expt. 3. ${ }^{2}$

\begin{tabular}{|c|c|c|}
\hline Parental and selection no. & Females $^{y}$ & Eggs + J2 \\
\hline Poncirus trifoliata Rubidoux & $0 \mathrm{c}$ & $0 \mathrm{~h}$ \\
\hline \multicolumn{3}{|c|}{ 'Cleopatra' mandarin $(03) \times$ P. trifoliata $(01)$} \\
\hline 03.01 .40 & $0 \mathrm{c}$ & $0 \mathrm{~h}$ \\
\hline 03.01 .8 & $0.003 \mathrm{c}$ & $0.3 \mathrm{~h}$ \\
\hline 03.01 .42 & $0.03 \mathrm{c}$ & $1.5 \mathrm{gh}$ \\
\hline 03.01 .5 & $0.06 \mathrm{c}$ & $5 \mathrm{fg}$ \\
\hline 03.01 .18 & $1 \mathrm{bc}$ & $11 \mathrm{ef}^{*}$ \\
\hline 03.01 .46 & $2 b^{*}$ & $30 \mathrm{de}^{*}$ \\
\hline \multicolumn{3}{|l|}{ 'King' mandarin $\times$ P. trifoliata } \\
\hline 05.01 .7 & $0.8 \mathrm{bc}$ & $19 \mathrm{ef}^{*}$ \\
\hline 05.01.24B & $1 \mathrm{bc}$ & $6 \mathrm{fg}$ \\
\hline \multicolumn{3}{|c|}{ 'Cleopatra' mandarin (03) x 'Troyer' citrange (02) } \\
\hline 03.02 .12 & $1.4 \mathrm{bc}$ & $42 \mathrm{~cd}^{*}$ \\
\hline \multicolumn{3}{|c|}{ 'Troyer' citrange (02) x 'Cleopatra' mandarin (03) } \\
\hline 02.03 .18 & $1.4 \mathrm{bc}$ & $20 \mathrm{de}^{*}$ \\
\hline 02.03 .24 & $2 b^{*}$ & $60 \mathrm{~cd}^{*}$ \\
\hline \multicolumn{3}{|l|}{ 'Troyer' Citrange $x$ common mandarin } \\
\hline 02.04 .18 & $10 a^{*}$ & $372 a^{*}$ \\
\hline X-639 & $14 \mathrm{a}^{*}$ & $216 a^{*}$ \\
\hline Sour orange & $7 a^{*}$ & $143 \mathrm{bc}^{*}$ \\
\hline Mean & 2.7 & 61.8 \\
\hline $\mathrm{CV}$ & 81.10 & 39.10 \\
\hline Dunnett's $t$ value, lower-tailed test & 2.87 & 2.87 \\
\hline MSE & 0.33 & 0.84 \\
\hline
\end{tabular}

tion in Spain. For instance, the selection 'Cleopatra' mandarin $\times$ P. trifoliata 03.01.5 has been recently released to nurseries because its resistance to CTV, higher tolerance to calcareous soils than 'Carrizo' citrange, and its ability to exclude chlorine is intermediate between 'Cleopatra' mandarin and 'Carrizo' citrange (Forner and Alcaide, 1994). This selection and 'Troyer' citrange $x$ common mandarin 02.04.18 (Table 3) have been registered for the European Union. New citrus rootstocks adapted to local conditions will contribute to diversification of the Spanish citrus industry which now relies on a few CTV-tolerant rootstocks (Forner and Pina, 1992).

Five of the 28 crosses with $P$. trifoliata studied differed from trifoliate orange in their reproductive potential but not in their infectivity. These crosses were 03.01.14 (Table 1), 03.01.47, 03.01.21, 03.01.46 (Table 2), 03.01.18, and 05.01.7 (Table 3). Females were not recovered from two to four of seven replicated plants of these crosses, which could explain their similarity in infectivity to the resistant standard. Overall, data on number of females were more variable than those on eggs $+\mathrm{J} 2$ per $\mathrm{g}$ of root in the three experiments, probably because of the low number of females recovered from some individual plants. The range of host susceptibilities for $T$. semipenetrans for the rootstocks tested in this study is probably similar to the variation reported previously (Geraci et al., 1981; Hutchinson and O'Bannon, 1972; McCarty et al., 1979; Niles et al., 1995). The rootstock selections that were included in the third experiment provided results similar to those obtained previously. Their host suitability to a population of the Mediterranean biotype of $T$. semipenetrans was confirmed. Further studies are needed to determine the performance of these resistant rootstocks under different field conditions. Also, the effect of inoculum pressure, heat sensitivity, disease complexes, and salinity should be determined (Mashela et al., 1992; Roberts, 1992). At present, we are evaluating the performance of the selection 03.01.5 in replant situations and the effect of initial and continuous inoculum pressure of the citrus nematode on several selections from crosses of "Cleopatra "mandarin $\times P$. trifoliata that showed resistance in the greenhouse tests. Although the Mediterranean biotype of $T$. semipenetrans has been the only citrus nematode biotype detected thus far in Spain (Verdejo-Lucas, 1992; Verdejo-Lucas et al., 1997b), the resistance of these new rootstocks to the citrus and Poncirus biotypes of $T$. semipenetrans should be assessed.

Tylenchulus semipenetrans has been the target nematode in screening tests of citrus and citrus relatives in California (Baines et al., 1960; Cameron et al., 1954; McCarty et al., 1979; Niles et al., 1995), Florida (Hutchinson and O'Bannon, 1972; O'Bannon and Ford, 1977), Italy (Geraci et al., 1981; Lo Giudice and Inserra, 1980), India (Chabra and Bindra, 1974; Reddy and Agarwal, 1987; Reddy et al., 1987), Israel (Spiegel-Roy et al., 1988), Venezuela (Crozzoli and González, 1989), China (Zhu et al., 1992), Brazil (Salibe and Jaehn, 
1996), and Spain (Verdejo-Lucas et al., 1997a). New rootstocks will be screened as they become available. Because T. semipenetrans is a highly specialized plant parasitic nematode, planting highly resistant rootstocks may exert selection pressure on the nematode, resulting in development of new biotypes that can reproduce on the resistant rootstocks. Nematode populations able to reproduce on trifoliate orange have been reported only from areas with a high incidence of $P$. trifoliata and its hybrids (Baines et al., 1969; Duncan et al., 1994). In practice, rootstocks with moderate levels of resistance would be desirable if they could provide adequate protection from nematode damage in the field; citrus trees can perform relatively well in soils with low nematode infestation levels.

This study used conventional plant breeding procedures to obtain the citrus hybrids. These procedures could be coupled with molecular techniques to expedite the plant breeding process. Currently, genetic markers linked to nematode resistance loci have been identified in other crops (Gebhardt, et al., 1993; Kreike et al., 1993; Salentijn et al., 1995; Weisemann et al., 1992; Williams et al., 1994; Williamson et al., 1994). Unfortunately, inheritance mechanisms for resistance to $T$. semipenetrans have not been determined. A dominant and oligogenic gene may be involved given the high frequency of $F_{1}$ hybrids of $P$. trifoliata that show resistance. (Cameron et al., 1969; Hutchinson, 1985). Histopathological studies have shown that the resistance to the citrus nematode derived from $P$. trifoliata is based on several mechanisms including a hypersensitivity response to early nematode feeding and subsequent formation of wound periderm (Kaplan, 1981; Kaplan and O'Bannon, 1981; Van Gundy and Kirkpatrick, 1964). Additional research is needed to determine mechanisms involved in the identification of molecular markers that link to the gene for T. semipenetrans resistance in P. trifoliata. Recently, random amplified polymorphic DNA fragment markers tightly linked to genes for resistance to citrus nematode and citrus tristeza virus have been identified (Gmitter et al., 1996; Mestre et al., 1997) in P. trifoliata. This finding is encouraging because both pathogens, the virus, and the nematode, appear to share the same source of genetic resistance.

\section{Literature Cited}

Baines, R.C., W.P. Bitters, and O.F. Clarke. 1960. Susceptibility of some species and varieties of citrus and some other rutaceous plants to the citrus nematode. Plant Dis. Rptr. 44:281-285.

Baines, R.C., T. Miyakawa, J.W. Cameron, and R. H. Small. 1969. Infectivity of two biotypes of the citrus nematode on citrus and some other hosts. J. Nematol. 1:150-159.

Bello, A., A. Navas, C. Belart, and M.P. Alvira. 1985. Los nematodos de los cítricos. Exmo. Ayuntamiento Catellón de la Plana.

Cameron, J.W., R.C. Baines, and O.F. Clarke. 1954. Resistance of hybrid seedlings of the trifoliate orange to infestation by the citrus nematode. Phytopathology 44:456-458.

Cameron, J.W., R.C. Baines, and R.K. Soost. 1969. Development of rootstocks resistant to the citrus

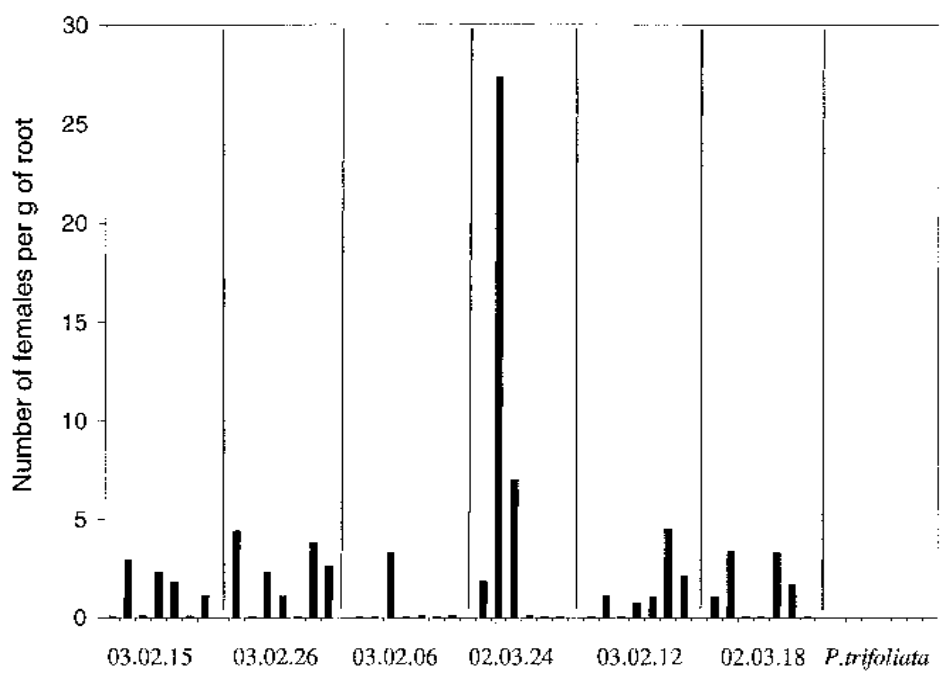

Fig. 1. Number of females per gram of root of a Mediterranean biotype of Tylenchulus semipenetrans 6 months after inoculation of $1 \times 10^{4}$ nematode eggs $+\mathrm{J} 2$ per plant in a greenhouse test. Each bar represents one of seven plants of selections from crosses of 'Troyer' citrange (02) with 'Cleopatra' mandarin (03).

Table 4. Root fresh weight and numbers of females and eggs $+\mathrm{J} 2$ per gram of root of a Mediterranean biotype of Tylenchulus semipenetrans on selections from crosses of 'Troyer' citrange and 'Cleopatra' mandarin.

\begin{tabular}{|c|c|c|c|c|c|}
\hline Expt. & Cross & $\begin{array}{c}\text { No. } \\
\text { selections }^{\mathrm{z}}\end{array}$ & $\begin{array}{c}\text { Root fresh } \\
\text { wt }(\mathrm{g})\end{array}$ & $\begin{array}{c}\text { Females } \\
\text { /g root }\end{array}$ & $\begin{array}{c}\text { Eggs }+\mathrm{J} 2 \\
/ \mathrm{g} \text { root }\end{array}$ \\
\hline \multirow[t]{2}{*}{1} & 'Troyer' x 'Cleopatra' & 4 & 18.0 & $6.4^{*}$ & $196^{*}$ \\
\hline & 'Cleopatra' x 'Troyer' & 6 & 20.6 & 3.7 & 101 \\
\hline \multirow[t]{2}{*}{2} & 'Troyer' x 'Cleopatra' & 4 & 16.6 & $18.4^{*}$ & 1323 \\
\hline & 'Cleopatra' x 'Troyer' & 4 & 15.0 & 31 & 884 \\
\hline \multirow[t]{2}{*}{3} & 'Troyer' x 'Cleopatra' & 2 & 24 & 1.8 & 40 \\
\hline & 'Cleopatra' x 'Troyer' & 1 & 20 & $1.4^{\mathrm{NS}}$ & 42 \\
\hline \multirow[t]{2}{*}{ Mean } & 'Troyer' x 'Cleopatra' & 10 & 18.8 & 611 & 10.2 \\
\hline & 'Cleopatra' x 'Troyer' & 11 & 18.6 & $373^{\mathrm{NS}}$ & 13.1 \\
\hline
\end{tabular}

${ }^{\mathrm{z}}$ Seven replicate plants per selection.

ss, *Nonsignificant or significantly different from reciprocal cross by Student's $t$ test, $P \leq 0.05$.

nematode, by breeding and selection, p. 949954. In: H.D. Chapman (ed.). Proc. $1^{\text {st }}$ Intl. Citrus Symp., Vol. 2. Univ. of California. Riverside.

Chabra, H.K., and O.S. Bindra 1974. Screening of citrus rootstocks against the citrus nematode, Tylenchulus semipenetrans Cobb, 1913. Indian J. Hort. 3:194-195.

Crozzoli, R., and C.C. Funes. 1992. Presencia del nematodo Tylenchulus semipenetrans en las principales zonas productoras de cítricos del estado de Aragua, Venezuela. Fitopatología Venezolana 5:17-20.

Crozzoli, R., and A. González. 1989. Reacción de once patrones de cítricos al nematodo Tylenchulus semipenetrans. Agron. Trop. 39:4-6.

Ducharme, E.P. 1948. Resistance of Poncirus trifoliata rootstock to nematode infestation in Argentina. The Citrus Ind. 29:9,15.

Duncan, L.W., and E. Cohn. 1990. Nematode diseases of citrus, p. 321-346. In: J. Bridge, M. Luc and R. Sikora (eds.). Plant parasitic nematodes in subtropical and tropical agriculture. Comwlth. Agr. Bur. Intl. Wallinform, UK

Duncan, L.W., R.N. Inserra, J.H. O'Bannon, and M.M. El-Morshedy. 1994. Reproduction of a Florida population of Tylenchulus semipenetrans on resistant citrus rootstocks. Plant Dis. 78:10671071.

Dunnett, C.W. 1955. A multiple comparison procedure for comparing several treatments with a control. J. Amer. Stat. Assn. 50:1096-1121.

Feder, W.A. 1968. Differential susceptibility of selections of Poncirus trifoliata to attack by the citrus nematode, Tylenchulus semipenetrans. Israel J. Agr. Res. 18:175-179.

Forner, J.B. and J.A.Pina. 1992. Plantones tolerantes a tristeza. Veinte años de historia (I). Patrones. Levante Agrícola 319:88-92.

Forner, J.B. and A. Alcaide. 1994. La mejora genética de patrones de agrios tolerantes a tristeza en España: 20 años de historia(II). Levante Agrícola 329:273-279.

Gebardt, C., E. Mugniery, E. Ritter, F. Salamini, and Bonnel. 1993. Identification of RFLP markers closely linked to the $\mathrm{H} 1$ gene conferring resistance to Globodera rostochiensis in potato. Theor. Appl. Genet. 85:541-544.

Geraci, G., V. Lo Giudice, and R.N. Inserra. 1981. Response of Citrus spp. and hybrid rootstocks to Tylenchulus semipenetrans. Riv. Ortoflorofrutt. Ital. 65:169- 172.

Gmitter, F.C. Jr., S.Y. Xiao, S. Huang, X.L., Hu, S.M. Garnsey, and Z. Deng. 1996. A localized linkage map of the citrus tristeza virus resistance gene region. Theor. Appl. Genet. 92:688-695.

Hutchinson, D.J. 1985. Rootstock development, screening and selection for disease tolerance and horticultural characteristics. Fruit Var. J. 39:21-25

Hutchinson, D.J. and J.H. O'Bannon, 1972. Evaluating the reaction of citrus selections to Tylenchulus semipenetrans. Plant Dis. Rptr. 56:747-751.

Jenkins, W.R. 1964. A rapid centrifugal flotation technique for separating nematodes from soil. Plant Dis. Rptr. 48:69.

Kaplan. D.T. 1981. Characterisation of citrus root- 
stock responses to Tylenchulus semipenetrans (Cobb.). J. Nematol. 13:492-498.

Kaplan, D.T. 1990. Screening for resistance to Tylenchulus semipenetrans and Radopholus species, p. 51-57 In: J. L. Starr (ed.). Methods for evaluating plant species for resistance to plantparasitic nematodes. Soc. Nematol. Hyattville, Md.

Kaplan, D.T. and J.H. O'Bannon. 1981. Evaluation and nature of citrus nematode resistance in 'Swingle' citrumelo. Proc. Florida State Hort. Soc. 94:33-36.

Kreike, C.M., J.R.A. de Koning, J.H. Vinke, J.W. Ooijen, C. Gebhardt, and W.J. Stiekman. 1993. Mapping of loci involved in quantitatively inherited resistance to the potato cyst-nematode Globodera rostochiensis pathotype Ro1. Theor. App. Genet. 87:464-470.

Lo Giudice, V. and R.N. Inserra. 1980. Reaction of citrus and noncitrus rootstocks to Tylenchulus semipenetrans. Nematologia Mediterranea 8:103-105.

Mashela, P., L.W. Duncan, and R. McSorley, 1992. Salinity reduces resistance to Tylenchulus semipenetrans in citrus rootstocks. Nematropica 22:7-12.

McCarty, C.D., W.P. Bitters, and S.D. Van Gundy, 1979. Susceptibility of 25 citrus rootstocks to the citrus nematode. HortScience 14:54-55.

McSorley, R., J.L. Parrado, and W.H. Dankers. 1984. A quantitative comparison of some methods for the extraction of nematodes from roots. Nematropica 14:72-84.

Mestre, P.F., M.J. Aíns, J.A. Pina, E.A Carbonell, and L. Navarro. 1997. Molecular markers flank 'King' citrus tristeza resistance gene from
Poncirus trifoliata (L.) Raf. Theor. Appl. Genet. 94:458-464.

Niles, R.K., D.W. Freckman, and M.L. Roose. 1995. Use of trifoliate orange as a comparative standard for assessing the resistance of citrus rootstocks to citrus nematode. Plant Dis. 79:813818.

O'Bannon J.H. and H.W. Ford. 1977. Resistance in citrus rootstock to Radopholus similis and Tylenchulus semipenetrans (Nematoda). Proc. Intl. Soc. Citricult. 2:544-549.

Reddy, P.P. and P.K. Agarwal. 1987. Resistance in citrus rootstocks to the citrus nematode Tylenchulus semipenetrans. Indian J. Hort. 44:111-114.

Reddy, P.P., R.M. Khan, and P.K. Agarwal, 1987. Selection of citrus rootstocks and hybrids resistant to the citrus nematode, Tylenchulus semipenetrans. Pakistan J. Nematol. 5:69-72.

Roberts, P.A. 1992. Current status of the availability development, and use of host plant resistance to nematodes. J. Nematol. 24: 213-227.

Salentijn, E.M.J., M.J.B. Arens-De Reuver, W. Lange, Th. S.M. De Bock, W.J. Steikema, and R.M. Klein-Lankhorst. 1995. Isolation and characterisation of RAPD-based markers linked to the beet cyst nematode resistance locus $(H s$ ${ }^{\text {pat-1 })}$ on chromosome 1 of $B$. patellaris. Theor. Appl. Genet. 90:885-891.

Salibe-A.B. and A. Jaehn. 1996. Reacao de doze porta-enxertos citricos ao nematoide Tylenchulus semipenetrans Cobb, 1913. Nematologia Brasileira 20:4-52.

Spiegel-Roy, P., A. Vardi, A. Elhanati, Z. Solel, and M. Bar-Joseph. 1988. Rootstock selections from a Poorman orange $\times$ P. trifoliata cross, p. 195-
200. In: R. Goren and K. Mendel (eds.). Proc. 6th Intl. Citrus Congr. Vol. I. Tel Aviv, Israel.

Van Gundy, S.D. and J.D. Kirkpatrick. 1964. Nature of resistance in certain citrus rootstocks to citrus nematodes. Phytopathology 54:419-427.

Verdejo-Lucas, S. 1992. On the occurrence of the 'Mediterranean biotype' of Tylenchulus semipenetrans in Spain. Fund. App. Nematology 15:475-477.

Verdejo-Lucas, S., F.J. Sorribas, J.B. Forner, and A. Alcaide. 1997a. Screening hybrid citrus rootstocks for resistance to Tylenchulus semipenetrans Cobb. Hortscience 32:1116-1119.

Verdejo-Lucas, S., F.J. Sorribas, J. Pons, J.B. Forner and A. Alcaide. 1997b. Biotypes of Tylenchulus semipenetrans from Spanish citrus orchards. Fund. App. Nematol. 20:399-404.

Weisemann, J.M., B.F. Mathew, T.E. Devine, 1992. Molecular markers located proximal to the soybean cyst nematode resistance gene Rhg4. Theor. Appl. Genet. 85:136-138.

Williams, K.J., J.M. Fisher, and P. Langridge. 1994. Identification of RFLP markers linked to the cereal cyst nematode resistance gene $(\mathrm{Cre})$ in wheat. Theor. Appl. Genet. 89:927-930.

Williamson, V.M., K.N. Lambert, I. Kaloshian. 1994. Molecular biology of nematode resistance in tomato, p.211-219. In: F. Lamberti, C. de Giorgi, and D.M. Bird (eds.). Advances in molecular plant nematology. Plenum Press, New York.

Zhu, W.S., H. Chen, X.Y.Lan, Q.Y.Chen, and K.M. Chian. 1992. Observation on the population of citrus root nematode in the soil and the resistance of different rootstocks. China-Citrus 22:1718. 